INTERNATIONAL MONETARY FUND

\author{
HONDURAS
}

\title{
Joint World Bank-IMF Debt Sustainability Analysis
}

July 2019

Prepared jointly by the staffs of the International Development Association (IDA)

and the International Monetary Fund (IMF)

Approved by Marcello Estevão (IDA), Patricia Alonso-Gamo, and Ana Corbacho, (IMF)

\begin{tabular}{|l|l|}
\hline \multicolumn{2}{|c|}{ Honduras: Joint Bank-Fund Debt Sustainability Analysis } \\
\hline Risk of external debt distress & Low \\
\hline Overall risk of debt distress & Low \\
\hline Granularity in the risk rating & Tool not applicable \\
\hline Application of judgment & No \\
\hline
\end{tabular}

The Debt Sustainability Analysis (DSA) indicates that Honduras stands at low risk of debt distress both for public external debt and overall debt, which represents an upgrade from the 2018 DSA, where risk of debt distress was assessed as moderate. ${ }^{1}$ The DSA was undertaken under the revised debt-sustainability framework for low income countries (LIC DSF), whereby Honduras's debt carrying capacity was upgraded from medium to strong. Changes in the debt-sustainability framework have contributed to the risk of debt distress improvement. A proven record of compliance with the Fiscal Responsibility Law (FRL) and solid macroeconomic conditions also contributed to rate Honduras' risk of debt distress as low. Going forward, adherence to the FRL and institutional reforms to boost inclusive growth and increase the economy's potential are critical to maintain debt sustainability.

\footnotetext{
${ }^{1}$ This DSA updates the previous joint IMF/WB DSA prepared in June 2018 in the context of the Honduras Article IV staff report (IMF Country Report No. 18/206).
} 


\section{Background}

1. Total public debt increased slightly in 2018 due mainly to higher domestic borrowing. Gross public debt stood at 41.8 percent of GDP at end-2018, up by almost 2 percentage points of GDP since 2017 (domestic debt comprising 1.4 percent the increase), of which 31 percentage points corresponded to external public and publicly guaranteed (PPG) debt and 10.8 percentage points to domestic debt (Text Table II.1). Regarding debt dynamics, the observed higher domestic real interest rates and real exchange rate depreciation (Table II.2) were partially offset by the contribution of real economic growth. The increase in domestic debt also portrays financial imbalances faced by the state-owned electricity company (ENEE).

2. PPG external debt increased slightly since 2016. Following a US\$700 million international bond issuance in 2017, the PPG external debt-to-GDP ratio increased to 31 percent in 2018. Total external debt reached 38.6 percent of GDP — up from 37.3 percent in 2017 — mainly driven by the increase in private external debt of 0.8 percent of GDP. Nonetheless, private external debt has declined somewhat over the last five years, easing from 9 percent of GDP in 2014 to 7.5 percent as of end 2018.

\begin{tabular}{|c|c|c|c|c|}
\hline \multirow{2}{*}{\multicolumn{5}{|c|}{ Text Table II.1. Honduras: PPG Debt Stock Composition by Level of Government }} \\
\hline & & & & \\
\hline & 2015 & 2016 & 2017 & 2018 \\
\hline \multicolumn{5}{|l|}{ Domestic Debt } \\
\hline Central government & 7.8 & 8.7 & 7.1 & 7.4 \\
\hline Local governments & 0.8 & 0.8 & 1.0 & 1.2 \\
\hline Nonfinancial public companies & 2.2 & 2.0 & 1.2 & 2.2 \\
\hline Total & 10.8 & 11.5 & 9.4 & 10.8 \\
\hline \multicolumn{5}{|l|}{ External Debt } \\
\hline Central government & 27.3 & 27.3 & 29.4 & 29.8 \\
\hline Local governments & 0.0 & 0.0 & 0.0 & 0.0 \\
\hline Nonfinancial public companies & 0.9 & 1.1 & 1.1 & 1.3 \\
\hline Total & 28.2 & 28.4 & 30.5 & 31.0 \\
\hline \multicolumn{5}{|l|}{ Total Debt } \\
\hline Central government & 35.1 & 36.0 & 36.5 & 37.2 \\
\hline Local governments & 0.8 & 0.8 & 1.0 & 1.2 \\
\hline Nonfinancial public companies & 3.1 & 3.1 & 2.4 & 3.5 \\
\hline Total & 39.0 & 39.9 & 39.9 & 41.8 \\
\hline \multicolumn{5}{|l|}{ Memorandum item } \\
\hline Private External Debt & 8.0 & 7.2 & 6.7 & 7.5 \\
\hline Source: Country authorities. & & & & \\
\hline
\end{tabular}


3. Public debt is mostly held by foreign creditors (Text Figure II.1). The share of PPG external debt stood at 74.2 percent of total public debt as of end 2018. The main creditors to Honduras are international bondholders, the Inter-American Development Bank (IDB), the Central American Bank for Economic Integration (CABEI), and the World Bank, which provide lending at long maturities, particularly in the case of the multilaterals. Public domestic debt is mainly held by commercial banks, has a shorter - though rising - maturity (over 4 years), and carries a higher real interest rate. In March 2018, the government placed a 15-year bond in the local market at a fixed interest rate of 11 percent raising 154 million Lempiras. This reflects a broader strategy by the authorities to increase Lempiras-denominated debt with longer maturities, to be held increasingly by pension funds and other institutional investors.

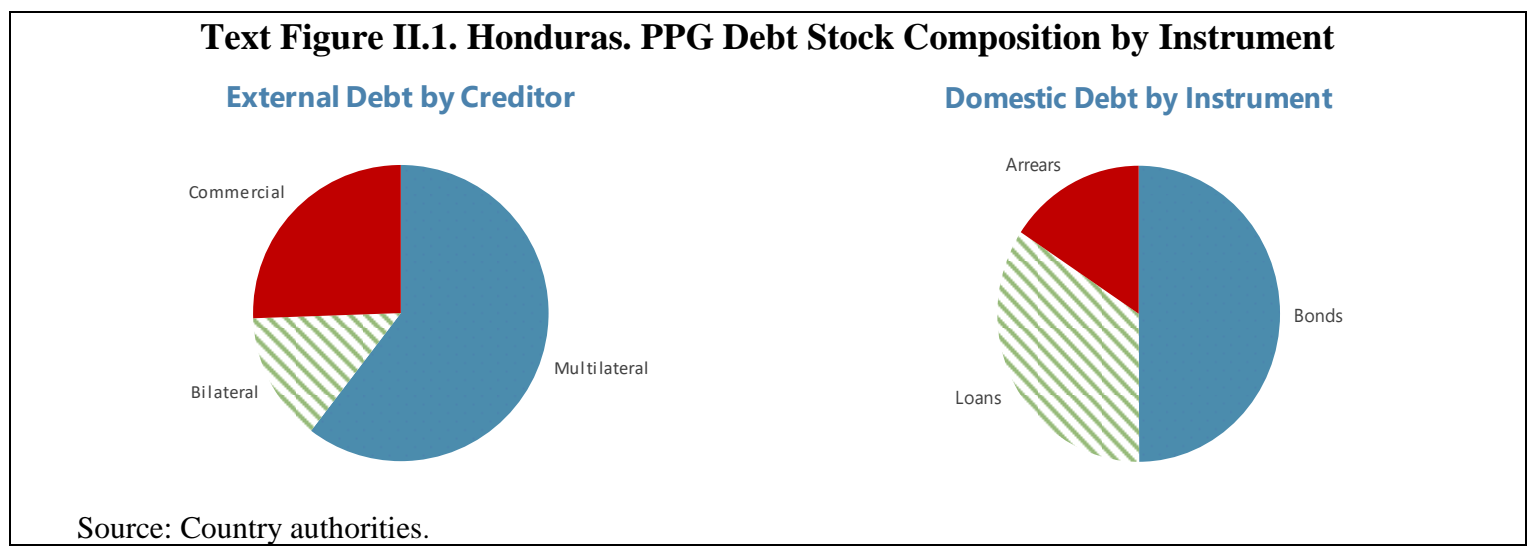

4. The debt coverage for the public sector is comprehensive. The DSA covers the nonfinancial public sector (NFPS). Therefore, it includes general government debt and nonfinancial state-owned enterprises' debt, both guaranteed and non guaranteed. Debt from extrabudgetary funds such as trust funds ${ }^{2}$ - which are treated as private entities under Honduran legislation but should be registered as general goverment units according to the 2014 GFSM-are also included (Text Table II.2). ${ }^{3}$ Decentralized agencies such as public universities, among others, are included. Public pension funds debt and central bank debt borrowed on behalf of the government are also covered in the debt stock. Among debt for non-financial SOEs, in the case of ENEE, this includes arrears to energy generators. The contingent liability test includes lawsuits related to labor and administrative disputes in the amount of 4 percent of GDP, ${ }^{4}$ PPPs for 4 percent of GDP, and the default financial market shock (5 percent of GDP). Since the DSA coverage does not include public banks, an additional 2 percent of GDP is added to the contingent liability test. The DSA uses a currency-based definition of external debt-non-residents do not hold domestic debt, hence there is no material difference between the residency-based and the currency-based

\footnotetext{
${ }^{2}$ Only the trust fund "Fondo de Protección y Seguridad Poblacional" has contracted debt.

${ }^{3}$ Where complete details on the debt service for local governments and trust funds are not available, conservative, commercial bank financing assumptions are used.

${ }^{4}$ Disputed amounts reach 9 percent of GDP, but contingent liabilities are 4 percent after factoring lawsuit-specific probabilities of resolution according to estimations prepared by the Treasury's contingency unit.
} 
concepts. Whereby, lempiras-denominated debt is considered public domestic debt and public foreign currency-denominated debt is accounted as public external debt.

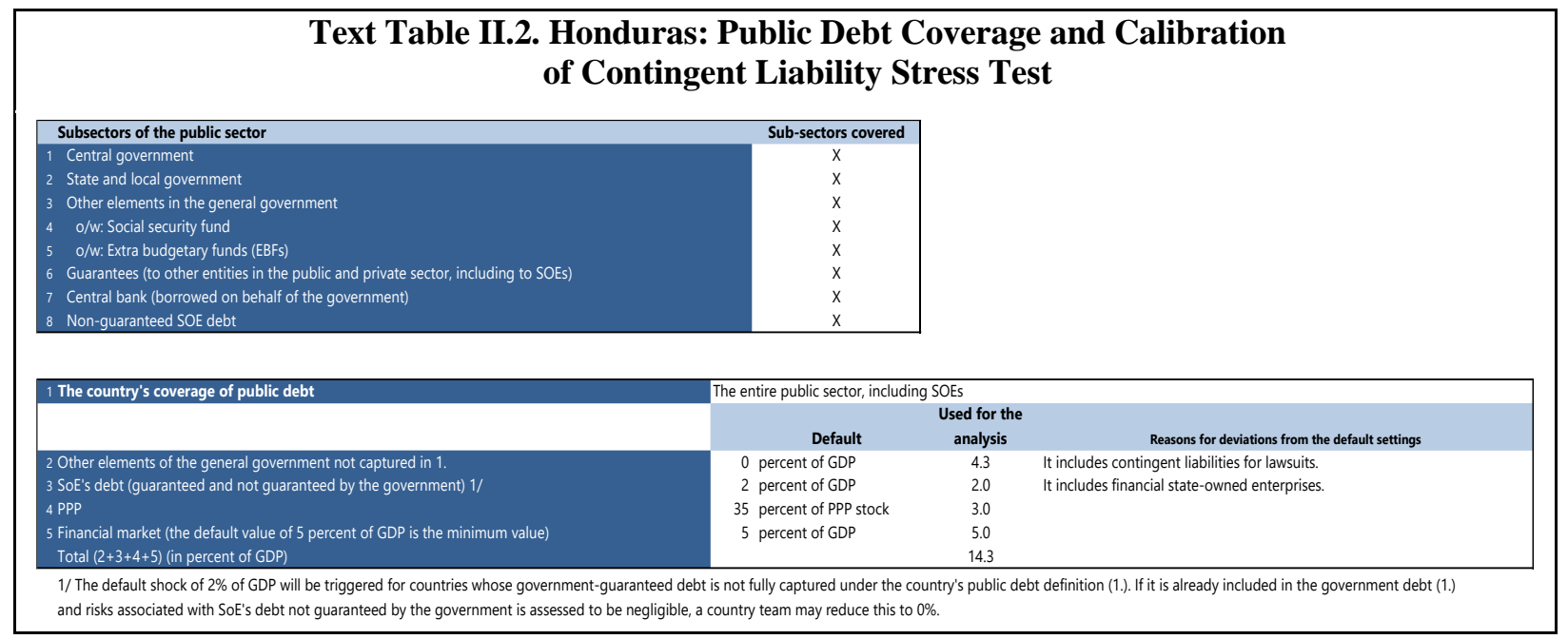

\section{Macroeconomic and Policy Assumptions}

5. The main macroeconomic assumptions are based on the authorities' policy targets and staff projections. The medium-to long-term macroeconomic outlook assumes that the FRL is fulfilled and that structural reforms envisaged in the Fund-supported program are implemented. As a result, the baseline macroeconomic projections are revised compared to the last DSA update dated June 2018 (Text Table II.3).

\begin{tabular}{|c|c|c|c|c|c|c|c|c|c|c|c|}
\hline \multicolumn{12}{|c|}{$\begin{array}{l}\text { Text Table II.3. Honduras: Selected Economic Indicators, } \\
\text { Current vs Previous DSA }\end{array}$} \\
\hline & 2016 & 2017 & 2018 & 2019 & 2020 & 2021 & 2022 & 2023 & 2024 & 2028 & 2038 \\
\hline \multicolumn{12}{|c|}{ Real GDP (percent change) } \\
\hline Current DSA & 3.8 & 4.9 & 3.7 & 3.4 & 3.5 & 3.6 & 3.7 & 3.9 & 3.9 & 3.9 & 3.9 \\
\hline Previous DSA & 3.8 & 4.8 & 3.7 & 3.7 & 3.7 & 3.7 & 3.8 & 3.8 & 3.8 & 3.8 & 3.8 \\
\hline \multicolumn{12}{|c|}{ GDP deflator (percent change) } \\
\hline Current DSA & 3.8 & 4.3 & 1.8 & 3.2 & 3.4 & 3.2 & 3.5 & 3.6 & 3.7 & 4.0 & 4.0 \\
\hline Previous DSA & 3.5 & 4.2 & 4.2 & 4.3 & 4.1 & 4.1 & 4.0 & 4.0 & 4.0 & 4.0 & 4.0 \\
\hline \multicolumn{12}{|c|}{ Primary balance (percent of GDP) } \\
\hline Current DSA & 0.3 & 0.1 & 0.0 & 0.6 & 0.7 & 0.8 & 1.0 & 0.9 & 0.9 & 0.8 & 1.1 \\
\hline Previous DSA & -0.7 & -0.4 & 0.2 & 0.5 & 0.7 & 0.6 & 0.5 & 0.6 & 0.6 & 0.7 & 0.7 \\
\hline \multicolumn{12}{|c|}{ Current account balance (percent of GDP) } \\
\hline Current DSA & -2.6 & -1.8 & -4.2 & -4.2 & -4.3 & -4.2 & -4.1 & -3.9 & -3.9 & -3.7 & -3.5 \\
\hline Previous DSA & -2.7 & -1.7 & -3.8 & -3.9 & -4.0 & -3.9 & -3.9 & -3.8 & -3.7 & -3.6 & -3.3 \\
\hline \multicolumn{12}{|c|}{ FDI (percent of GDP) } \\
\hline Current DSA & 4.1 & 4.4 & 4.8 & 4.9 & 4.9 & 4.9 & 4.9 & 4.9 & 4.9 & 4.9 & 4.9 \\
\hline Previous DSA & 4.5 & 4.2 & 4.4 & 4.2 & 4.2 & 4.3 & 4.3 & 4.3 & 4.4 & 4.5 & 4.7 \\
\hline
\end{tabular}


- Real sector. GDP growth estimates are broadly unchanged with respect to the previous DSA. Compared to the baseline projections in the 2018 DSA, the increased FDI level in 2019 is expected to be maintained over the projection period, supported by the structural reforms implemented during the program. Inflation is projected at about 4 percent, in line with the Central Bank's target.

- $\quad$ Fiscal variables. ${ }^{5}$ Fiscal projections assume compliance with the FRL, which sets a NFPS deficit limit of 1 percent of GDP from 2019 onwards and a limit to the increase for current spending at the budgetary central government level — which should be below the average real economic growth of the previous 10 years plus the inflation target (leading to about 7 percent in nominal terms). Guided by the FRL deficit target and by an increase in public pension funds' investment in central government debt, the NFPS debt is expected to decrease over the medium-term, as intra public sector financing will be increasing.

- Debt issuance assumptions. The share of external borrowing from multilateral and bilateral institutions is expected to remain broadly constant on average over the medium-term. These projections assume that existing Eurobonds will be rolled over, and as a result the grantelement of the overall financing is expected to be lower in the years when Eurobonds are issued (reaching about 20 percent). The share of external financing in total financing is expected to remain constant (at about 75 percent) in the medium-term and to start declining in the long-run (to about 60 percent). The projections also envisage that the authorities succeed in deepening the domestic debt market, increasing maturities and issuing predominantly at fixed rates. These assumptions are consistent with the Honduran Debt Management Strategy.

- External sector. In 2018 and 2019, the current account deteriorated as a result of unfavorable terms of trade shocks. The current account deficit is projected to hover around 4 percent of GDP over the medium term; and reach 31/2 percent of GDP in the longer term reflecting an improvement in the trade balance as Honduras heightens its competitiveness and penetration of export markets. A decline in external public sector interest payments - as the stock of external debt decreases - explains the lower current account deficits towards the end of the projection period. In the outer years, the current account deficit is expected to be financed primarily by foreign direct investment. This outcome would allow for international reserves to remain above 5 months of non-maquila imports throughout the projection period. FDI is expected to increase in critical economic sectors such as electricity.

\footnotetext{
${ }^{5}$ Historical fiscal figures have changed as a result of data revisions and progressive consolidation of additional government units into the nonfinancial public sector statistics as required by the FRL.
} 
6. The realism tools suggest that the projections are reasonable (Figures II.3 and II.4). ${ }^{6,7}$ The baseline assumes an improvement of the primary balance of 0.5 percentage points of GDP over the next three years, which falls in the third quartile of the distribution for LICs. This improvement in the primary balance is warranted by compliance with the FRL, which serves as an anchor to guide fiscal sustainability. Compared to the previous DSA, both growth projections and the evolution of investment are similar. The projected contribution of the government's capital stock to growth remains in line with the historical levels and the growth path assumes reasonable levels for the fiscal multiplier.

\section{Country Classification}

7. Honduras debt carrying capacity is classified as strong under the revised LIC DSF. Debt carrying capacity is determined by a composite indicator (CI) that includes the World Bank's Country Policy and Institutional Assessment (CPIA) score, world economic growth, and Honduras's real growth rate, import coverage of reserves, and remittances. Two consecutive signals are needed to modify the classification, which has been the case for Honduras since the implementation of the revised LIC DSF with a CI classification of strong debt carrying capacity in April and October 2018. The current April 2019 vintage also yields a rating of strong debt carrying capacity (Text Table II.4). Under the previous methodology (CPIA-based), Honduras debt carrying capacity was classified as medium (Text Table II.5).

\begin{tabular}{|c|c|c|c|c|}
\hline \multicolumn{5}{|c|}{ Text Table II.4. Honduras: Calculation of the Composite Indicator } \\
\hline Components & Coefficients (A) & $\begin{array}{l}\text { 10-year average values } \\
\text { (B) }\end{array}$ & $\begin{array}{l}\text { CI Score components } \\
\qquad\left(A^{*} B\right)=(C)\end{array}$ & $\begin{array}{l}\text { Contribution of } \\
\text { components }\end{array}$ \\
\hline CPIA & 0.385 & 3.482 & 1.34 & $42 \%$ \\
\hline Real growth rate (in percent) & 2.719 & 3.676 & 0.10 & $3 \%$ \\
\hline $\begin{array}{l}\text { Import coverage of reserves (in } \\
\text { percent) }\end{array}$ & 4.052 & 40.340 & 1.63 & $51 \%$ \\
\hline $\begin{array}{l}\text { Import coverage of reserves }{ }^{\wedge} 2 \text { (in } \\
\text { percent) }\end{array}$ & -3.990 & 16.273 & -0.65 & $-20 \%$ \\
\hline Remittances (in percent) & 2.022 & 15.494 & 0.31 & $10 \%$ \\
\hline World economic growth (in percent) & 13.520 & 3.559 & 0.48 & $15 \%$ \\
\hline CI Score & & & 3.22 & $100 \%$ \\
\hline Cl rating & & & Strong & \\
\hline
\end{tabular}

\footnotetext{
${ }^{6}$ Realism tools are designed to encourage examination of baseline assumptions and cover (i) drivers of debt dynamics, (ii) realism of planned fiscal adjustment, (iii) fiscal adjustment-growth relationship, and (iv) public investment-growth relationship.

${ }^{7}$ Weaknesses in private net foreign assets data could explain in part historical residuals.
} 


\begin{tabular}{|c|c|c|c|}
\hline \multicolumn{4}{|c|}{ Text Table II.5. Honduras: Debt Carrying Capacity Country Classification } \\
\hline Final & $\begin{array}{c}\text { Classification based on } \\
\text { current vintage }\end{array}$ & $\begin{array}{l}\text { Classification based on } \\
\text { the October } 2018 \text { vintage }\end{array}$ & $\begin{array}{c}\text { Classification based on the } \\
\text { April } 2018 \text { vintage } \\
\end{array}$ \\
\hline Strong & $\begin{array}{l}\text { Strong } \\
3.22\end{array}$ & $\begin{array}{l}\text { Strong } \\
3.21\end{array}$ & $\begin{array}{l}\text { Strong } \\
3.21\end{array}$ \\
\hline
\end{tabular}

8. A strong debt-carrying capacity implies higher thresholds for the stress tests. For countries classified as having a strong debt carrying capacity, such as Honduras, the corresponding indicative thresholds are the following: 55 percent for the present value (PV) of PPG external debtto-GDP ratio; 240 percent for the PV of PPG external debt-to-exports ratio; 21 percent for the PPG external debt service-to-exports ratio; and 23 percent for the PPG debt service-to-revenue ratio. The applicable benchmark for total public debt in the case of Honduras is 70 percent for the PV of total public debt-to-GDP ratio (Text Table II.6).

\begin{tabular}{|c|c|c|c|}
\hline \multicolumn{4}{|c|}{$\begin{array}{c}\text { Text Table II.6. Honduras: Public and Publicly Guaranteed (PPG) External Debt Thresholds } \\
\text { and Total Public Debt Benchmarks }\end{array}$} \\
\hline EXTERNAL debt burden thresholds & Weak & Medium & Strong \\
\hline \multicolumn{4}{|l|}{ PV of debt in \% of } \\
\hline Exports & 140 & 180 & 240 \\
\hline GDP & 30 & 40 & 55 \\
\hline \multicolumn{4}{|l|}{ Debt service in \% of } \\
\hline Exports & 10 & 15 & 21 \\
\hline Revenue & 14 & 18 & 23 \\
\hline TOTAL public debt benchmark & & We & Medium \\
\hline PV of total public debt in percent of GDF & & 3 & 55 \\
\hline
\end{tabular}

\section{External DSA}

9. Honduras's risk of external debt distress is assessed to be low. The PV of PPG external debt-to-GDP ratio is projected to peak at 27.8 percent in 2019, below the 55 percent threshold (Table II.3). The PPG external debt service-to exports and PPG external debt service-to-revenue peak in 2019, well under their respective thresholds of 21 percent and 23 percent, respectively. Consequently, all solvency and liquidity indicators under the baseline scenario and under various stress tests remain below their respective thresholds (Figure II.1). The peaks observed on debt service indicators are explained by the repayments of Eurobonds (in 2019, 2022, 2026, 2029) and the CABEI bullet repayment in 2025 .

10. However, some debt indicators are sensitive to shocks. A negative shock to exports, equivalent to a one standard deviation decline in the nominal growth of exports in the second and third years of projection and a decline in real GDP growth, generates the largest increase in the PV 
of the PPG external debt-to-GDP ratio, leading to a peak of 44.5 percent in 2021 (Figure II.1). Under the same shock, the PPG external debt-to-exports ratio would peak in 2021, reaching 135.4 percent (below the 240 percent threshold). Furthermore, the same shock would lead the PPG external debt-service-to-exports ratio to reach 17.1 percent in 2026, and the PPG external debtservice to revenue ratio to peak at 17.7 in 2026, in both cases well-below the risk thresholds.

11. Accessing the SBA/SCF arrangements would not jeopardize debt sustainability. If the SBA/SCF arrangements were to be accessed, the PV of PPG external debt-to-GDP ratio would peak at 28.4 percent in 2020, still below the 55 percent threshold. Similarly, PPG external debt service-to exports and PPG external debt service-to-revenue would peak in 2026 at 11.6 and 14.9, respectively, both well under their respective thresholds. All solvency and liquidity indicators would also remain below their thresholds under all the stress tests.

\section{Public DSA}

12. Public debt ratios are expected to peak in 2019, and then decline over the medium term. Public debt is projected to peak at 42.1 percent of GDP in 2019 and start declining, supported by stable primary surpluses of around 1 percent of GDP as well as declining interest payments, reaching 36.1 percent of GDP by 2029 (Table II.4 and Figure II.2). The FRL is the critical difference between baseline projections and the historical scenario, providing an anchor for a sound fiscal position. In present value terms, the debt-to-GDP ratio is expected to peak at 37.5 percent of GDP in 2019 and fall to 31.6 percent of GDP by 2029. Public debt dynamics remain somewhat vulnerable to both policy-related and exogenous shocks, especially to those related to fiscal policy and exports (Table II.4). However, under no scenario does any of the indicators breach its benchmark. Thresholds would not be breached either if the SBA/SCF arrangements were to be accessed.

13. The exposure to contingent liabilities seems to be limited, except for materialization of downside risks facing SOEs. Upgraded PPP accounting rules to international standards has enabled the impact of PPP operations to be included into the regular public-sector spending and financing recording. In addition, the new contingency unit at the Ministry of Finance (SEFIN) is effectively taking stock of and limiting fiscal exposure from PPPs. The cost of clearing ENEE's growing pending liabilities (estimated at around 1.1 percent of GDP at end-December 2018) is included in the baseline macroeconomic projections through a comprehensive reform program that will include debt refinancing and operational gains. But if this process ends-up being more onerous than currently anticipated it could translate into a negative shock to the PV of public debt.

\section{Market-Financing Risk Indicators suggest potentially low liquidity requirements} (Figure II.5). The maximum gross financing needs over a 3-year period under the baseline projection horizon in Honduras are expected to be around 7 percent of GDP, which is below the benchmark value of 14 percent. In addition, current EMBI spreads of 283 basis points are substantially below the benchmark level of 570 basis points. In addition, the PV of debt relative to 
GDP and to exports, as well as the ratios of debt service to exports and to revenue, are all expected to remain below the thresholds under the baseline projection and under the market financing scenario. Nevertheless, given significant uncertainty regarding global financial conditions, a cautious debt management approach is warranted.

\section{Conclusion}

15. The DSA indicates that Honduras's risks of external debt and public total debt distress are low, supported by strict observance of the FRL. This updated risk rating is an improvement from the previous moderate risk rating from the 2018 DSA and reflects also the upgrade in the debt carrying capacity assessment to strong, under the revised DSF methodology. PPG external debt burden indicators remain below the thresholds under the baseline scenario and stress tests. Nonetheless, shocks affecting exports or economic growth showcase existing debt vulnerabilities, implying that adhering consistently to the FRL is a key element to ensuring debt sustainability. The results also highlight the importance of raising domestic revenue, addressing structural vulnerabilities in SOEs, and leveraging concessional sources of financing when available.

\section{Authorities' Views}

16. Authorities agreed with the change in the risk rating following the application of the revised LIC DSF. They noted their commitment to adhere to the FRL, preserving the revenue mobilization efforts while implementing reforms in SOEs to resolve their imbalances, and to the further development of the domestic debt market. The contingency unit at SEFIN will continue addressing data limitations with the goal of improving the management of fiscal risks. 


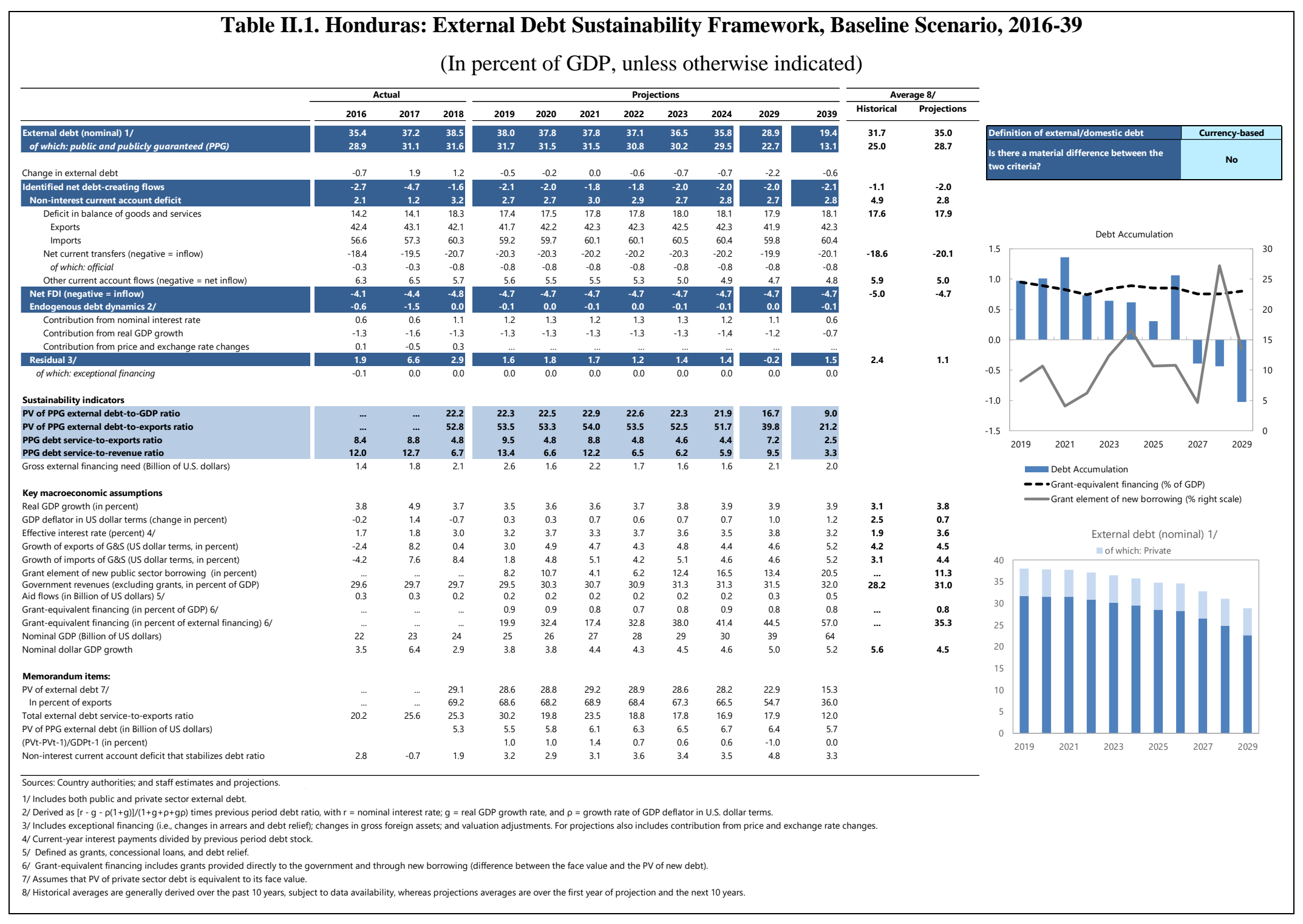




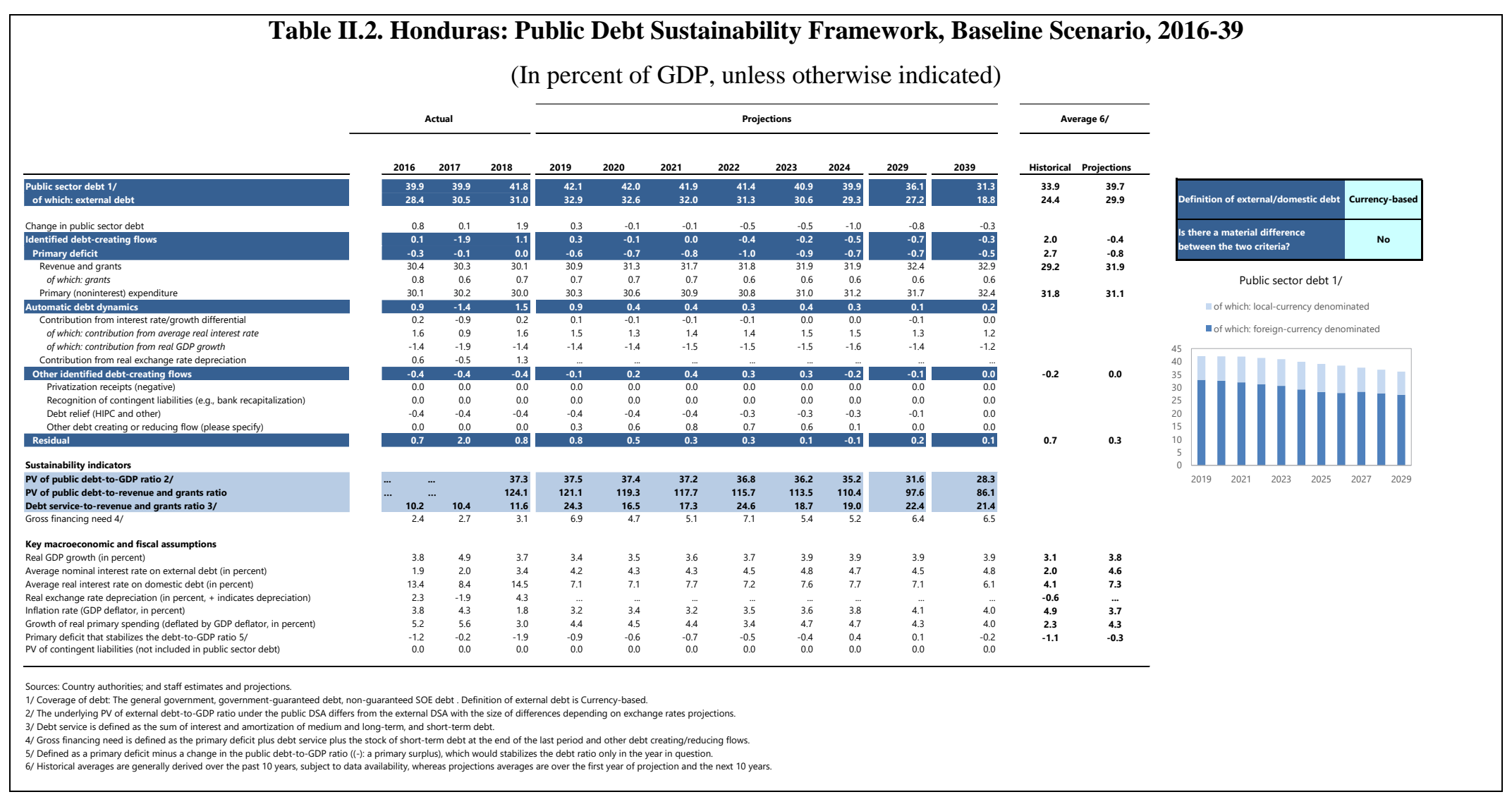




\section{Figure II.1. Honduras: Indicators of Public and Publicly Guaranteed External Debt under}

Alternative Scenarios, 2019-29
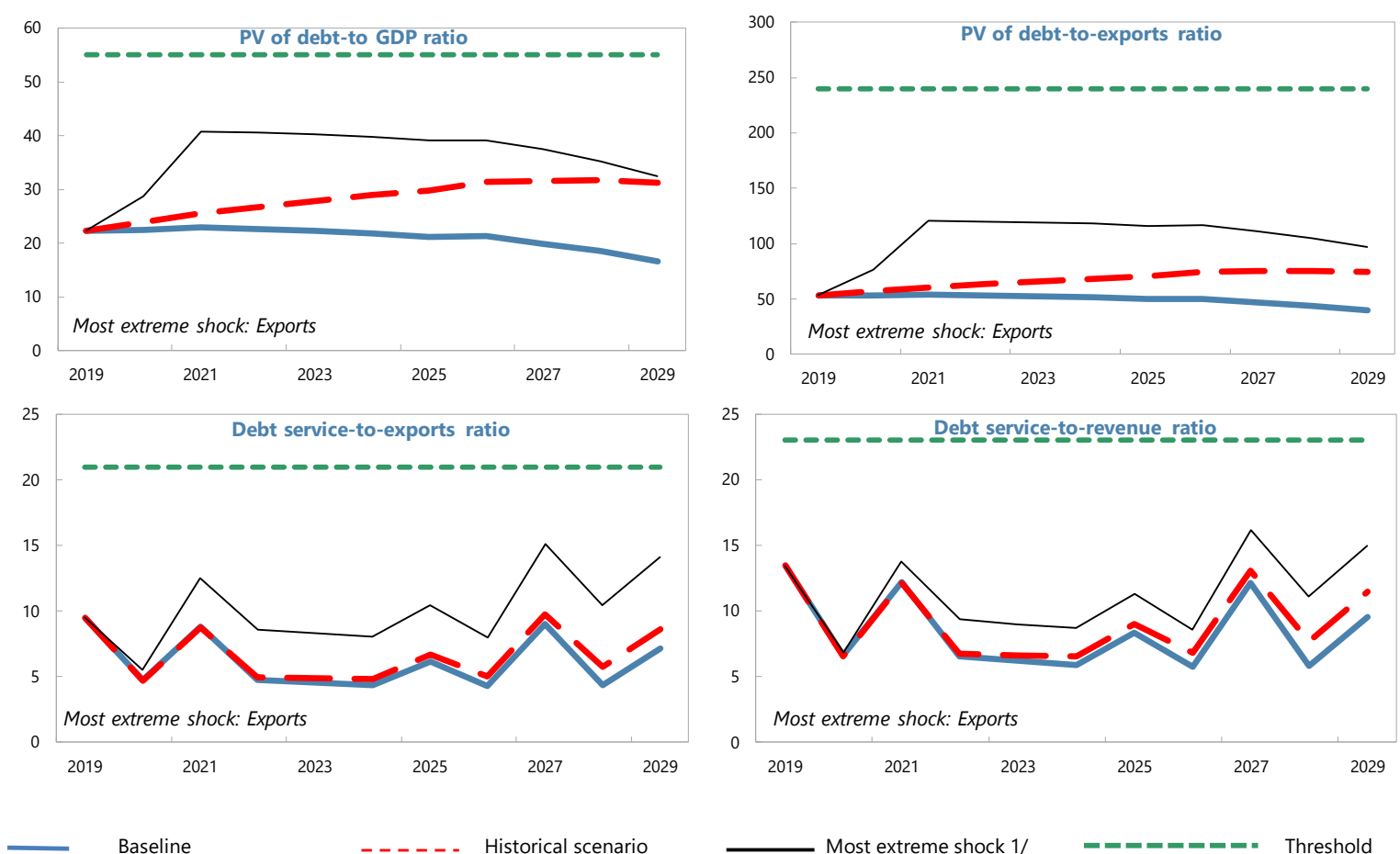

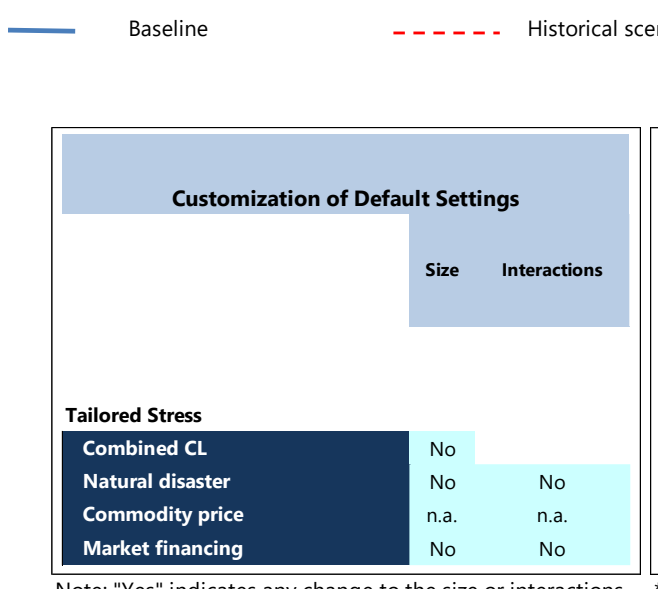

Note: "Yes" indicates any change to the size or interactions of the default settings for the stress tests. "n.a." indicates that the stress test does not apply.

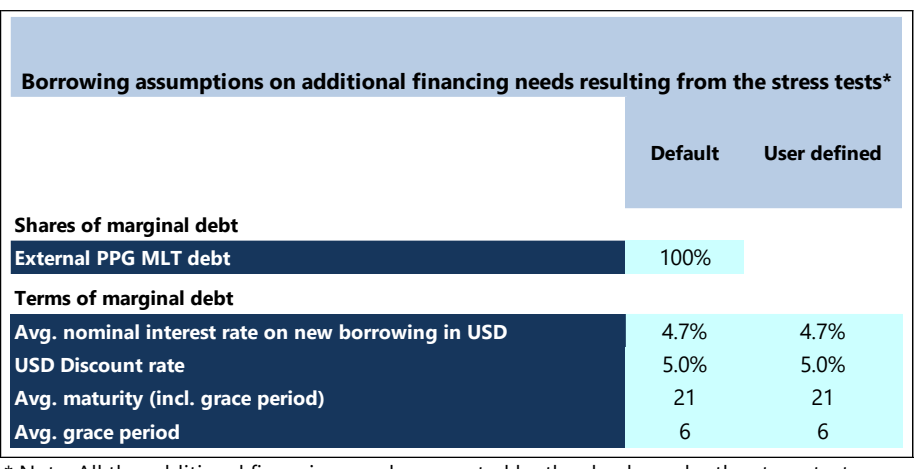

* Note: All the additional financing needs generated by the shocks under the stress tests are assumed to be covered by PPG external MLT debt in the external DSA. Default terms of marginal debt are based on baseline 10-year projections.

Sources: Country authorities; and staff estimates and projections.

1 / The most extreme stress test is the test that yields the highest ratio in or before 2029. The stress test with a one-off breach is also presented (if any), while the one-off breach is deemed away for mechanical signals. When a stress test with a one-off breach happens to be the most exterme shock even after disregarding the one-off breach, only that stress test (with a one-off breach) would be presented. 
Figure II.2. Honduras: Indicators of Public Debt under Alternative Scenarios, 2019-29

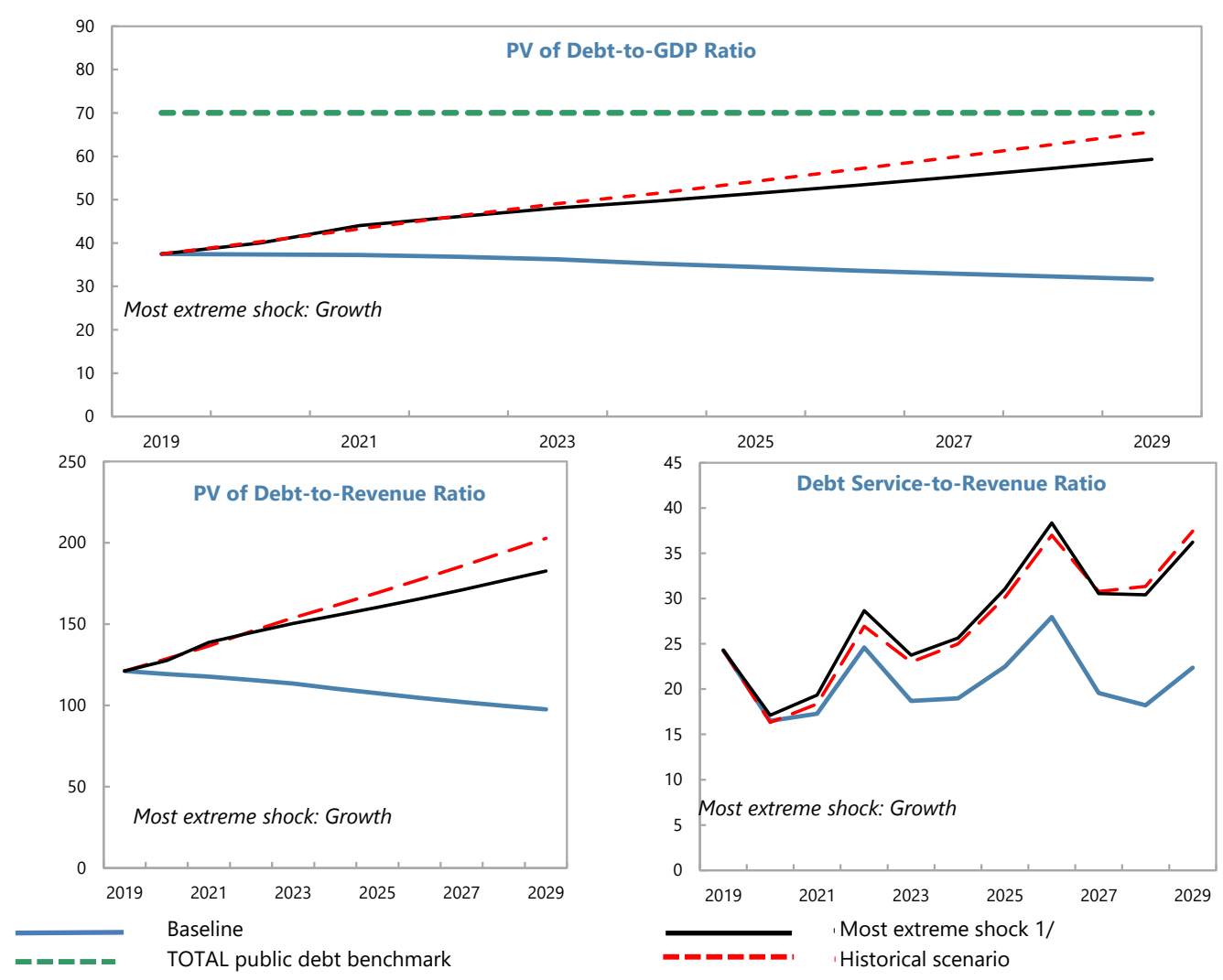

\begin{tabular}{|l|c|c|}
\hline \multicolumn{1}{|c|}{$\begin{array}{c}\text { Borrowing assumptions on additional financing needs resulting from the stress } \\
\text { tests* }\end{array}$} & Default & User defined \\
\hline Shares of marginal debt & $45 \%$ & $45 \%$ \\
External PPG medium and long-term & $54 \%$ & $54 \%$ \\
Domestic medium and long-term & $0 \%$ & $0 \%$ \\
Domestic short-term & & \\
\hline Terms of marginal debt & $5.1 \%$ & $5.1 \%$ \\
\hline External MLT debt & 20 & 20 \\
Avg. nominal interest rate on new borrowing in USD & 6 & 6 \\
Avg. maturity (incl. grace period) & $6.7 \%$ & $6.7 \%$ \\
Avg. grace period & 5 & 5 \\
Domestic MLT debt & 0 & 0 \\
Avg. real interest rate on new borrowing & & \\
Avg. maturity (incl. grace period) & $0.0 \%$ & $0.0 \%$ \\
Avg. grace period & & \\
Domestic short-term debt & & \\
Avg. real interest rate &
\end{tabular}

* Note: The public DSA allows for domestic financing to cover the additional financing needs generated by the shocks under the stress tests in the public DSA. Default terms of marginal debt are based on baseline 10-year projections.

Sources: Country authorities; and staff estimates and projections.

1/ The most extreme stress test is the test that yields the highest ratio in or before 2029. The stress test with a one-off breach is also presented (if any), while the one-off breach is deemed away for mechanical signals. When a stress test with a one-off breach happens to be the most exterme shock even after disregarding the one-off breach, only that stress test (with a one-off breach) would be presented. 
Table II.3. Honduras: Sensitivity Analysis for Key Indicators of Public and Publicly Guaranteed External Debt, 2019-29

\begin{tabular}{|c|c|c|c|c|c|c|c|c|c|c|c|}
\hline & \multicolumn{11}{|c|}{ Projections 1/ } \\
\hline & 2019 & 2020 & 2021 & 2022 & 2023 & 2024 & 2025 & 2026 & 2027 & 2028 & 2029 \\
\hline \multicolumn{12}{|c|}{ PV of debt-to GDP ratio } \\
\hline Baseline & 28 & 28 & 27 & 26 & 26 & 24 & 23 & 23 & 23 & 23 & 22 \\
\hline \multicolumn{12}{|l|}{ A. Alternative Scenarios } \\
\hline A1. Key variables at their historical averages in 2019-2029 2/ & 28 & 29 & 30 & 32 & 33 & 34 & 35 & 37 & 40 & 42 & 43 \\
\hline \multicolumn{12}{|l|}{ B. Bound Tests } \\
\hline B1. Real GDP growth & 28 & 29 & 29 & 28 & 28 & 26 & 25 & 25 & 25 & 25 & 24 \\
\hline B2. Primary balance & 28 & 30 & 35 & 35 & 35 & 34 & 34 & 34 & 35 & 35 & 34 \\
\hline B3. Exports & 28 & 34 & 44 & 44 & 43 & 42 & 41 & 40 & 41 & 39 & 38 \\
\hline B4. Other flows $3 /$ & 28 & 33 & 38 & 37 & 36 & 35 & 34 & 34 & 34 & 33 & 32 \\
\hline B5. Depreciation & 28 & 35 & 26 & 25 & 24 & 23 & 22 & 21 & 22 & 21 & 21 \\
\hline B6. Combination of B1-B5 & 28 & 38 & 42 & 41 & 41 & 39 & 38 & 38 & 38 & 37 & 35 \\
\hline \multicolumn{12}{|l|}{ c. Tailored Tests } \\
\hline C1. Combined contingent liabilities & 28 & 34 & 34 & 35 & 35 & 34 & 34 & 34 & 35 & 35 & 35 \\
\hline C2. Natural disaster & 28 & 33 & 33 & 33 & 33 & 33 & 33 & 33 & 34 & 35 & 35 \\
\hline C3. Commodity price & n.a. & n.a. & n.a. & n.a. & n.a. & n.a. & n.a. & n.a. & n.a. & n.a. & n.a. \\
\hline C4. Market Financing & 28 & 31 & 30 & 29 & 29 & 27 & 26 & 26 & 26 & 26 & 25 \\
\hline Threshold & 55 & 55 & 55 & 55 & 55 & 55 & 55 & 55 & 55 & 55 & 55 \\
\hline \multicolumn{12}{|c|}{ PV of debt-to-exports ratio } \\
\hline Baseline & 68 & 68 & 66 & 65 & 63 & 60 & 58 & 56 & 58 & 57 & 55 \\
\hline \multicolumn{12}{|l|}{ A. Alternative Scenarios } \\
\hline A1. Key variables at their historical averages in 2019-2029 2/ & 68 & 72 & 74 & 77 & 81 & 84 & 88 & 92 & 99 & 103 & 107 \\
\hline \multicolumn{12}{|l|}{ B. Bound Tests } \\
\hline B1. Real GDP growth & 68 & 68 & 66 & 65 & 63 & 60 & 58 & 56 & 58 & 57 & 55 \\
\hline B2. Primary balance & 68 & 74 & 86 & 86 & 86 & 85 & 84 & 84 & 87 & 86 & 85 \\
\hline B3. Exports & 68 & 92 & 135 & 133 & 131 & 128 & 125 & 123 & 124 & 120 & 116 \\
\hline B4. Other flows 3 / & 68 & 81 & 93 & 91 & 89 & 87 & 84 & 83 & 84 & 81 & 79 \\
\hline B5. Depreciation & 68 & 68 & 51 & 49 & 47 & 44 & 42 & 41 & 42 & 42 & 42 \\
\hline B6. Combination of B1-B5 & 68 & 94 & 95 & 106 & 105 & 102 & 99 & 98 & 98 & 95 & 92 \\
\hline c. Tailored Tests & & & & & & & & & & & \\
\hline C1. Combined contingent liabilities & 68 & 84 & 84 & 85 & 85 & 85 & 85 & 84 & 87 & 87 & 86 \\
\hline C2. Natural disaster & 68 & 82 & 83 & 83 & 83 & 83 & 83 & 84 & 87 & 87 & 87 \\
\hline C3. Commodity price & n.a. & n.a. & n.a. & n.a. & n.a. & n.a. & n.a. & n.a. & n.a. & n.a. & n.a. \\
\hline C4. Market Financing & 68 & 68 & 66 & 65 & 63 & 61 & 58 & 57 & 59 & 57 & 56 \\
\hline Threshold & 240 & 240 & 240 & 240 & 240 & 240 & 240 & 240 & 240 & 240 & 240 \\
\hline & ice-to-e & ports $r$ & & & & & & & & & \\
\hline Baseline & 11 & 6 & 6 & 10 & 6 & 6 & 8 & 11 & 5 & 6 & 9 \\
\hline A. Alternative Scenarios & & & & & & & & & & & \\
\hline A1. Key variables at their historical averages in 2019-2029 2/ & 11 & 6 & 6 & 10 & 6 & 7 & 9 & 12 & 7 & 8 & 12 \\
\hline B. Bound Tests & & & & & & & & & & & \\
\hline B1. Real GDP growth & 11 & 6 & 6 & 10 & 6 & 6 & 8 & 11 & 5 & 6 & 9 \\
\hline B2. Primary balance & 11 & 6 & 6 & 12 & 7 & 7 & 9 & 13 & 7 & 8 & 12 \\
\hline B3. Exports & 11 & 7 & 9 & 16 & 10 & 10 & 13 & 17 & 10 & 12 & 17 \\
\hline B4. Other flows $3 /$ & 11 & 6 & 7 & 12 & 7 & 7 & 9 & 12 & 7 & 8 & 12 \\
\hline B5. Depreciation & 11 & 6 & 6 & 10 & 5 & 5 & 7 & 10 & 5 & 4 & 8 \\
\hline B6. Combination of B1-B5 & 11 & 6 & 8 & 13 & 8 & 8 & 11 & 14 & 9 & 10 & 14 \\
\hline c. Tailored Tests & & & & & & & & & & & \\
\hline C1. Combined contingent liabilities & 11 & 6 & 7 & 11 & 7 & 7 & 9 & 12 & 7 & 7 & 11 \\
\hline C2. Natural disaster & 11 & 6 & 7 & 11 & 7 & 7 & 9 & 13 & 7 & 7 & 11 \\
\hline C3. Commodity price & n.a. & n.a. & n.a. & n.a. & n.a. & n.a. & n.a. & n.a. & n.a. & n.a. & n.a. \\
\hline C4. Market Financing & 11 & 6 & 6 & 10 & 6 & 6 & 9 & 12 & 10 & 5 & 9 \\
\hline Threshold & 21 & 21 & 21 & 21 & 21 & 21 & 21 & 21 & 21 & 21 & 21 \\
\hline & ce-to-r & enue $r$ & & & & & & & & & \\
\hline Baseline & 14 & 8 & 8 & 14 & 8 & 8 & 10 & 14 & 7 & 7 & 12 \\
\hline A. Alternative Scenarios & & & & & & & & & & & \\
\hline A1. Key variables at their historical averages in 2019-2029 2/ & 14 & 8 & 8 & 14 & 8 & 9 & 11 & 15 & 9 & 10 & 15 \\
\hline B. Bound Tests & & & & & & & & & & & \\
\hline B1. Real GDP growth & 14 & 8 & 8 & 15 & 8 & 8 & 11 & 16 & 8 & 8 & 13 \\
\hline B2. Primary balance & 14 & 8 & 8 & 15 & 10 & 9 & 12 & 16 & 9 & 10 & 15 \\
\hline B3. Exports & 14 & 8 & 9 & 17 & 11 & 11 & 13 & 18 & 11 & 12 & 17 \\
\hline B4. Other flows $3 /$ & 14 & 8 & 9 & 15 & 9 & 9 & 12 & 16 & 9 & 10 & 15 \\
\hline B5. Depreciation & 14 & 10 & 10 & 16 & 9 & 8 & 12 & 17 & 8 & 6 & 12 \\
\hline B6. Combination of B1-B5 & 14 & 8 & 10 & 17 & 11 & 10 & 13 & 18 & 11 & 12 & 17 \\
\hline c. Tailored Tests & & & & & & & & & & & \\
\hline C1. Combined contingent liabilities & 14 & 8 & 9 & 15 & 9 & 9 & 12 & 16 & 9 & 9 & 14 \\
\hline C2. Natural disaster & 14 & 8 & 8 & 14 & 9 & 9 & 11 & 16 & 8 & 9 & 13 \\
\hline C3. Commodity price & n.a. & n.a. & n.a. & n.a. & n.a. & n.a. & n.a. & n.a. & n.a. & n.a. & n.a. \\
\hline C4. Market Financing & 14 & 8 & 8 & 14 & 8 & 8 & 11 & 15 & 12 & 7 & 11 \\
\hline Threshold & 23 & 23 & 23 & 23 & 23 & 23 & 23 & 23 & 23 & 23 & 23 \\
\hline
\end{tabular}


Table II.4. Honduras: Sensitivity Analysis for Key Indicators of Public Debt, 2019-29

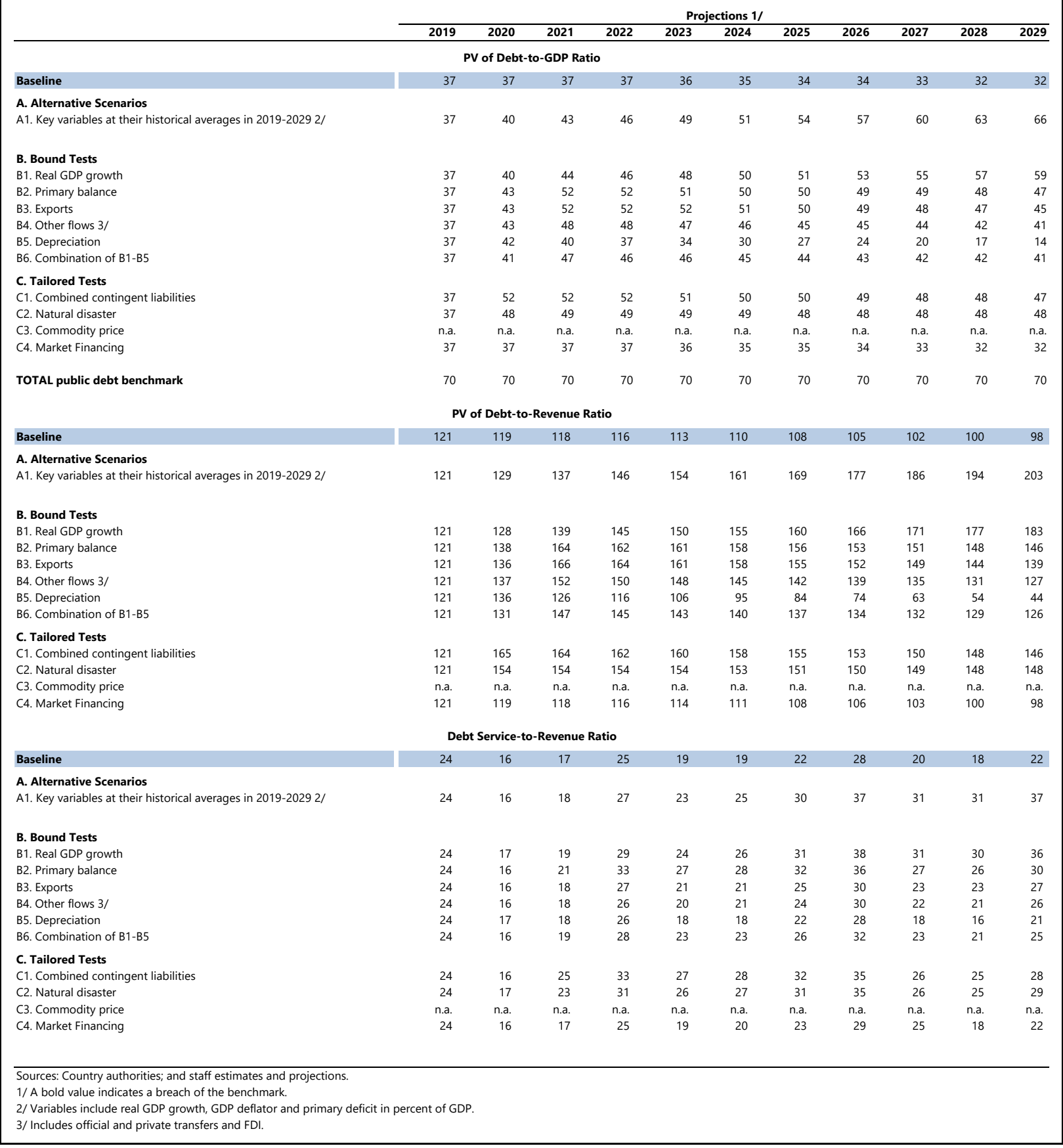


Figure II.3. Honduras: Drivers of Debt Dynamics - Baseline Scenario
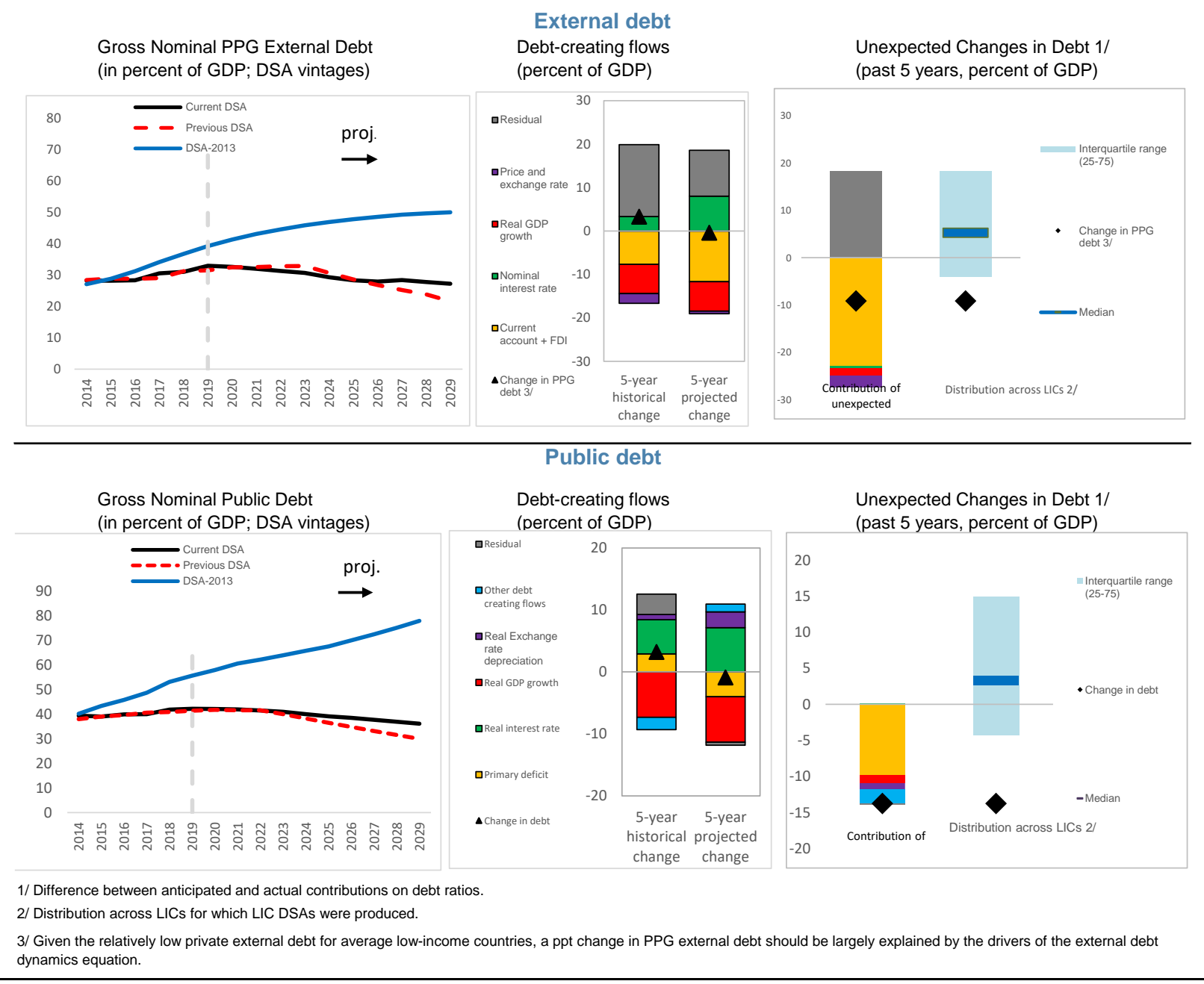


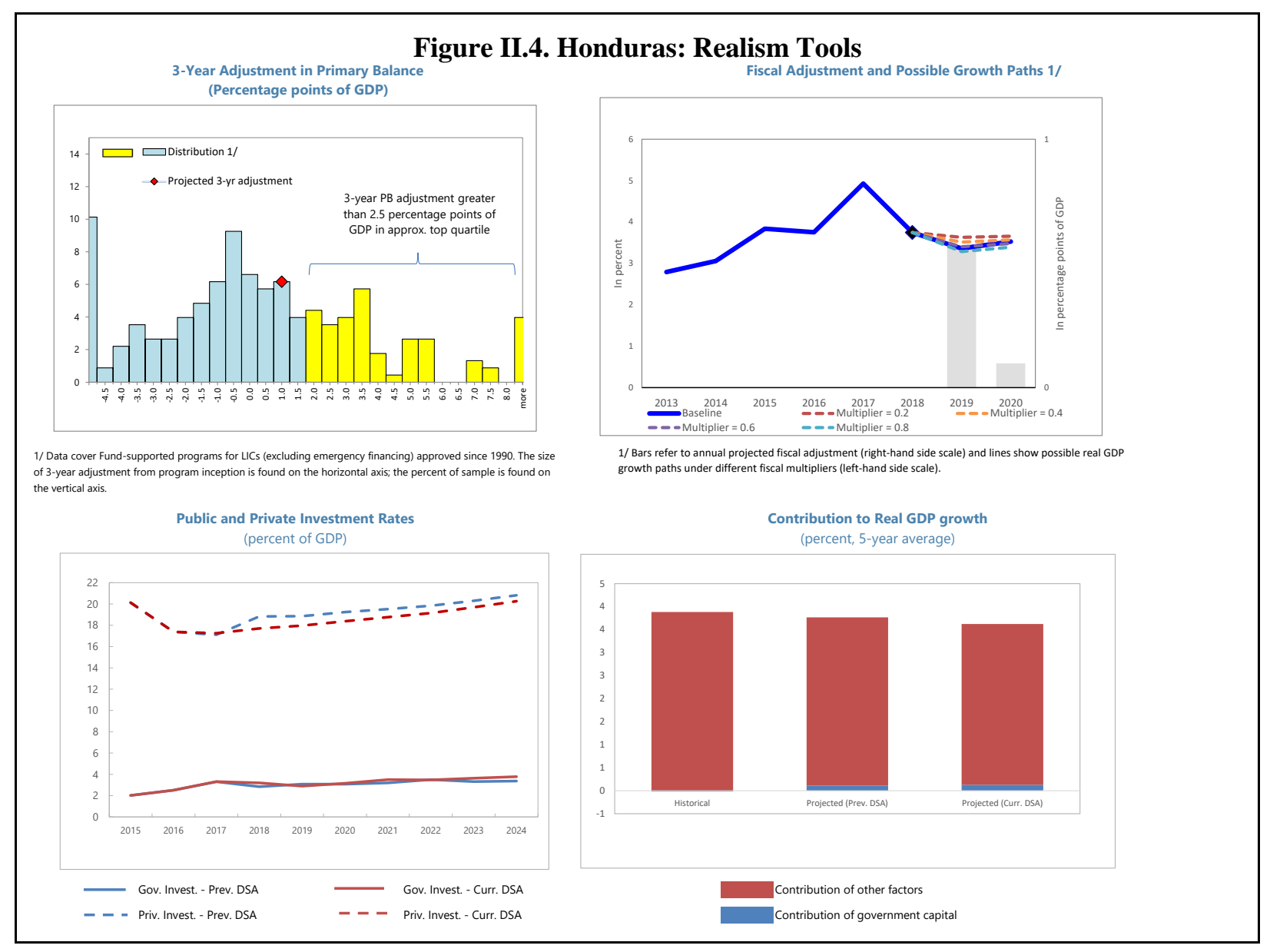


Figure II.5. Honduras: Market-Financing Risk Indicators

\begin{tabular}{|c|c|c|c|}
\hline & GFN & $1 /$ & $\mathrm{EMBI}$ \\
\hline Benchmarks & 14 & & 570 \\
\hline Values & 7 & & 283 \\
\hline Breach of benchmark & No & & No \\
\hline $\begin{array}{l}\text { Potential heightened } \\
\text { liquidity needs }\end{array}$ & Low & & \\
\hline
\end{tabular}

1/ Maximum gross financing needs (GFN) over 3-year baseline projection horizon.

2/ EMBI spreads correspond to the latest available data.
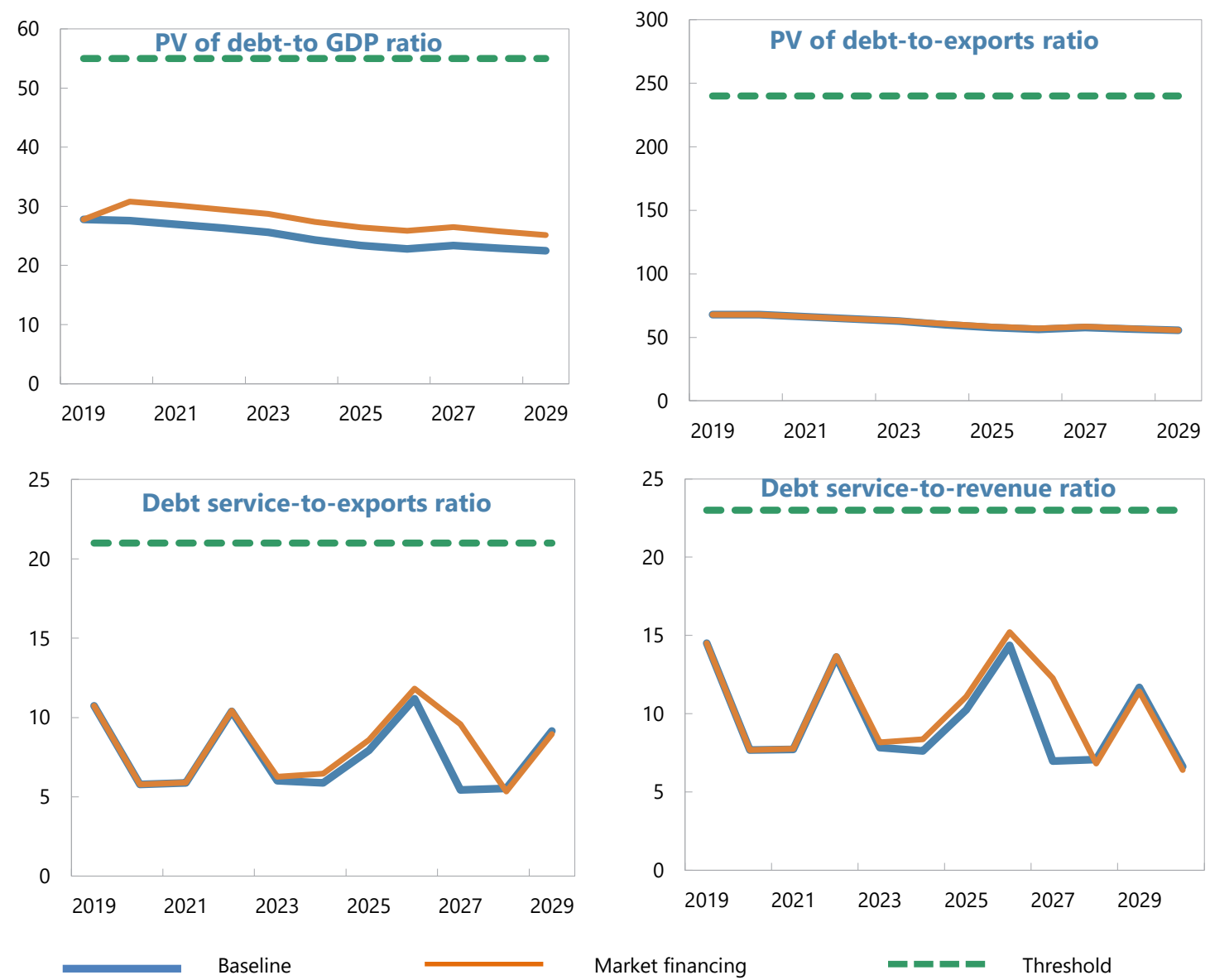

Sources: Country authorities; and staff estimates and projections. 